\title{
Augmented Reality Pengenalan Huruf dan Angka Arab Menggunakan Metode Marker Based Tracking Berbasis Android
}

\author{
Maurizka Zahra Devita*, Septi Andryana, Deny Hidayatullah \\ Fakultas Teknologi Komunikasi dan Informatika, Informatika, Universitas Nasional, Jakarta, Indonesia \\ Email: ${ }^{*}$ maurizkadevita10@ gmail.com, ${ }^{2}$ septi.andryana@civitas.unas.ac.id, ${ }^{3}$ deny @ civitas.unas.ac.id \\ $\left.{ }^{*}\right)$ Email Penulis Koresponsi: maurizkadevita10@gmail.com
}

\begin{abstract}
Abstrak-Huruf Hijaiyah adalah huruf arab yang berada di dalam Al-Quran yang dipelajari oleh orang muslim. Jumlah Huruf Hijaiyah yang umumnya diketahui total 30 huruf. Penelitian ini bertujuan untuk memberikan pengenalan huruf hijaiyah, angka arab, dan alphabet pada smartphone android dengan menerapkan Augmented Reality dengan media buku marker sebagai penanda munculnya objek sehingga pembelajaran menjadi lebih menarik. Dari penelitian terdahulu, hal yang sudah dibahas adalah aplikasi Augemented Reality hanya mengenalkan huruf hijaiyah dan Alphabet menggunakan media kartu dengan rekomendasi jarak $30 \mathrm{~cm}$ dan rekomendasi sudut $60^{\circ}-90^{\circ}$. Aplikasi ini dibangun menggunakan Unity 3D, Vuforia SDK dengan algoritma FAST Corner Detection serta objek 3D dibuat menggunakan Blender. Aplikasi ini memanfaatkan metode marker yang digunakan guna menentukan titik munculnya objek 3D. Hasil pengujian validasi menyimpulkan jika semua sistem valid. Pengujian algoritma dengan titik $\mathrm{x} 1, \mathrm{y} 1, \mathrm{x} 2$ dan $\mathrm{y} 2$, kondisi kamera terhadap marker rekomendasi jarak adalah $50 \mathrm{~cm}$ dengan sudut $45^{\circ}$ serta jarak $50 \mathrm{~cm}-60 \mathrm{~cm}$ dengan sudut $90^{\circ}$.
\end{abstract}

Kata Kunci: Augmented Reality, Marker, Huruf, Unity 3D, Angka Arab

\begin{abstract}
Hijaiyah letters are Arabic letters that are in the Koran which are studied by Muslims. Number of Hijaiyah Letters which are generally known to total 30 letters. This study aims to provide an introduction hijaiyah letters, Arabic numerals and alphabets on android smartphone by applying Augmented Reality with the media guide as a marker emergence marker object so that learning becomes more attractive. From previous research, things that have been discussed are only introduces the application Augemented Reality hijaiyah and Alphabet letters using a media card with a distance of $30 \mathrm{~cm}$ recommendations and recommendations $60^{\circ}-90^{\circ}$ corner. This application is built using the Unity 3D, Vuforia SDK with FAST Corner Detection algorithm and 3D objects created using Blender. This application uses the marker method used to determine the point of emergence of 3D objects. The results of validation testing concluded if all valid system. Testing algorithms with the point $\mathrm{x} 1, \mathrm{y} 1, \mathrm{x} 2$ and $\mathrm{y} 2$, condition of the camera to the marker on the distance is $50 \mathrm{~cm}$ at an angle of $45^{\circ}$ and a distance of 50 $\mathrm{cm}-60 \mathrm{~cm}$ at an angle of $90^{\circ}$.
\end{abstract}

Keywords: Augmented Reality, Marker, Alphabet, Unity 3D, Arabic Numerals

\section{PENDAHULUAN}

Perkembangan teknologi pada zaman ini membawa dampak yang dignifikan, penemuan baru dari berbagai jenis teknologi memberikan solusi untuk mengatasi berbagai permasalahan yang ada. Hal inilah yang memberikan dampak bagi manusia yang membutuhkan sebuah media untuk membantu mengenalkan pembelajaran huruf hijaiyah, angka arab dan Alphabet berbasis Augmented Reality dengan media buku kepada anak usia dini yang menimba ilmu di Taman Kanak-Kanak Islam atau paud. Augmented Reality merupakan teknologi yang menampakan lingkungan fisik nyata dengan gambar yang dihasilkan komputer sehingga mengubah presepsi realitas [1]. Dengan dibuatkannya Augmented Reality, minat belajar pada anak-anak di Taman Kanak-Kanak menjadi menarik dan kreatif.

Huruf Hijaiyah adalah huruf arab yang berada di dalam Al-Quran yang dipelajari oleh orang muslim.

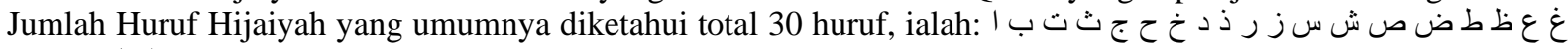
ه : Bilangan angka arab ialah penyebutan sepuluh digit angka yaitu 0, 1, 2, 3, 4, 5, 6, 7, 8, 9

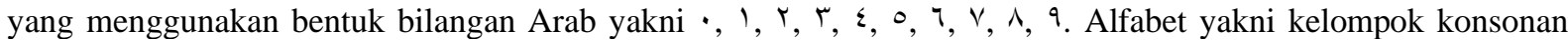
atau aksara yang terstruktur berlandaskan rangkaian yang normal atau sistem aksara yang melambangkan pengucapan bahasa yang dipakai untuk mencantumkan kata-kata atau bahasa yang terdiri dari A sampai Z [2].

Penelitian ini diharapkan dapat membantu anak-anak usia dini dalam mengenal bentuk dari huruf hijaiyah, angka arab dan alphabet serta bagaimana pelafalannya dari setiap huruf. Adapun tujuan penelitian ini yakni untuk mengonsep serta menciptakan aplikasi Augmented Reality pengenalan huruf hijaiyah, angka arab dan alphabet berbasis android dan membuat tampilan objek 3D disertai suara dengan metode marker based dan Vuforia SDK yang mencakup algoritma FAST Corner Detection. Manfaat dari penelitian ini adalah untuk membantu anak usia dini dalam pengenalan huruf hijaiyah, angka arab dan alphabet sehingga minat belajar menjadi lebih menarik dan kreatif.

Dalam penelitian ini terdapat beberapa jurnal sebagai acuan atau sebagai pembanding. Jurnal pertama membahas Augmented Reality pembelajaran huruf hijaiyah menggunakan metode marker based dengan jarak pendeteksian yang tepat dalam memunculkan huruf hijaiyah, pada jurnal ini tidak terdapat algoritma serta pengujian algoritma, hanya menampilkan pengujian intensitas cahaya [3]. Pada jurnal kedua membahas augmented reality Bahasa isyarat pengenalan huruf hijaiyah dengan hasil objek 3D menggunakan tangan yang menunjukkan Bahasa isyarat. Algoritma yang dipakai pada jurnal ini adalah algoritma greedy, dengan pengujian jarak pada suatu marker, namun tidak terdapat tampilan aplikasi [4]. Pada jurnal ketiga membahas Augemented 
Reality pada pengenalan hijaiyah alphabet dengan menampilkan suara dan objek 3D dengan algoritma FAST Corner Detection, pada jurnal ini menjelaskan alur algoritma serta rumus algoritma, namun tidak terdapat pengujian jarak pada suatu algoritma [5]. Pada jurnal ke empat membahas untuk mengembangkan aplikasi augmented reality pengenalan dasar huruf hijaiyah menggunakan animasi dan suara, metode yang dipakai ada Marker Based Tracking. Proses berjalannya aplikasi hanya menggunakan satu marker sehingga memudahkan pengguna, pada jurnal ini tidak dijelaskan algoritma, pengujian yang dilakukan adalah pengujian waktu proses aplikasi [6]. Pada jurnal keenam menggunakan teknik Marker dengan sistem menampilkan objek 3D, suara dan teks pada huruf. Prosen aplikasi menggunakan media kartu sehingga menjadi daya tarik bagi pengguna, algoritma yang dipakai adalah yang dipakai adalah FAST Corner Detection, namun tidak dijelaskan pengujian algoritma tersebut [7]. Jurnal ke tujuh membahas augmented reality yang dibuat buku untuk pengenalan alphabet, metode yang digunakan adalah Marker Based Tracking. Pada jurnal ini tidak terdapat algoritma, namun terdapat pengujian jarak dan sudut [8]. Pada penelitian ini, menerapkan Augmented Reality dengan metode Marker Based Tracking yang terdapat tiga fitur yakni pengenalan huruf hijaiyah, angka arab dan alphabet beserta audio pelafalannya dan lagu untuk sistem belajar anak-anak usia dini yang sedang melangsungkan pendidikan di Taman Kanak-Kanak Islam atau Paud yang diharapkan mampu menarik minat anak-anak guna memahami dan mengkajinya.

\section{METODE PENELITIAN}

\subsection{Kerangka Penelitian}

Kerangka penelitian adalah tahapan yang menjelaskan langkah-langkah untuk menyelesaikan masalah. Adapun kerangka penelitian dapat dilihat pada gambar 1 sebagai berikut:

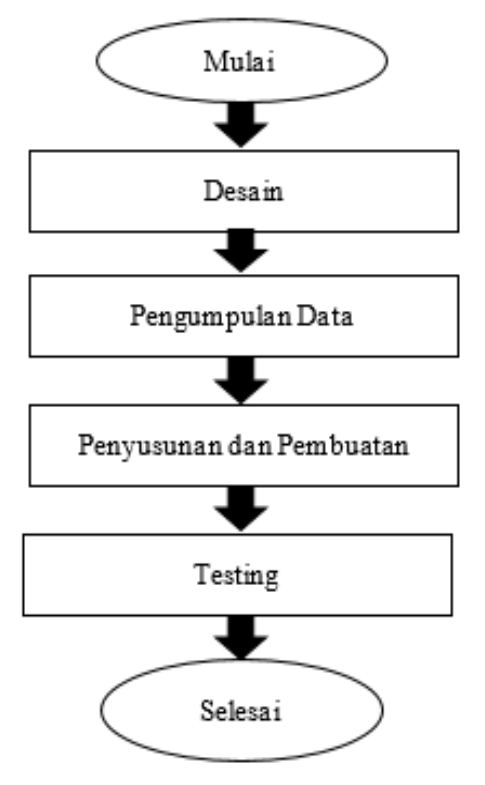

Gambar 1. Kerangka Penelitian

Penjelasan kerangka penelitian pada gambar 1 adalah sebagai berikut:

a. Desain

Pada fase ini pembuatan spesifikasi mengenai rancangan program, tampilan dan kebutuhan material atau bahan untuk program.

b. Pengumpulan Data

Proses pengumpulan data mengenai objek yang akan ditampilkan, kemudian data multimedia seperti gambar, dan audio yang akan dimasukkan pada aplikasi. Pada aplikasi ini bahan yang dibutuhkan yaitu objek yang berupa huruf hijaiyah, alphabet dan angka arab dalam bentuk 3D, dan marker objek menggunakan kamera vuforia. yang berfungsi sebagai pengenalan.

c. Penyusunan dan Pembuatan

Pada fase ini seluruh objek atau bahan multimedia yang sudah didapat kemudian disusun sesuai desain, setelah tersusun masuk ke tahap pembuatan aplikasi menggunakan Unity3D.

d. Testing (Pengujian)

Pada fase ini yakni pengujian yang dilakukan dengan menjalankan aplikasi serta pengujian identifikasi marker, pengujian ini akan diamati apakah ada kesalahan atau tidak. 


\subsection{Flowchart Aplikasi}

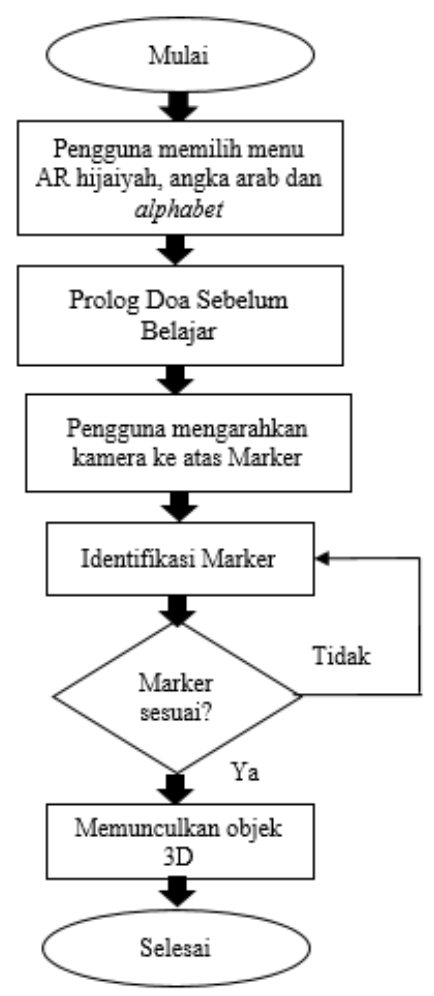

Gambar 2. Flowchart Aplikasi

Penjelasan dari Flowchart aplikasi pada gambar 2 adalah sebagai berikut:

a. Mulai. Pengguna memilih menu AR hijaiyah, angka arab dan alphabet.

b. Menjalankan aplikasi, lalu pilih tombol Hijaiyah, alphabet dan angka arab.

c. Menampilkan prolog doa sebelum belajar.

d. Mengarahkan kamera smartphone ke atas marker.

e. Identifikasi Marker, jika berhasil maka akan muncul objek 3D, jika gagal maka ada kesalahan marker.

f. Jika sudah selesai tekan tombol home guna kembali ke menu utama, dan tombol close atau keluar untuk mengakhiri aplikasi.

\subsection{Augmented Reality}

Augmented Reality adalah sebuah pendekatan untuk memvisualisasikan maya di atas citra fisik dan memanipulasi informasi maya melalui interaksi dengan objek realworld [9]. AR memiliki dua metode yakni Markerless Based Tracking dan Marker Based Tracking, pada penelitian ini digunakan metode Marker Based Tracking, metode ini menggunakan marker yang berbentuk ilustrasi hitam dan putih persegi yang mempunyai batasan bewarna hitam tebal dan berlatar belakang putih kemudian diimport ke dalam library atau Vuforia SDK [10].

\subsection{Algoritma Fast Corner Detection}

FAST (Feture Form Accelerated Segment Test) Corner Detection ialah suatu algoritma yang berfungsi untuk mendeteksi sudut-sudut dari suatu objek. Algoritma ini bertujuan untuk menurunkan tingkat akurasi pada deteksi sudut secara real-time [11]. Fast Corner Detection dimulai dengan menentukan titik pusat $(p)$ dengan koordinat $(x p, y p)$ pada citra yang digunakan sebagai marker. Pada FAST Corner Detection, proses Cornernya adalah mengubah.citra atau marker menjadi warna hitam putih (grayscale) dan algoritma mulai diproses [12]. Algoritma ini menentukan titik pusat dari gambar masukan dengan 16 pixel. Di samping titik p akan diperiksa 3 kasus yang berbeda yakni [13]:

Penjelasan:

$$
C=\left\{\begin{array}{l}
I_{p}-I_{n}<t, \text { normal } \\
I_{n}-I_{p}>t, \text { brighter } \\
I_{p}-I_{n}>t \text { darker }
\end{array}\right.
$$

In $=$ titik intensitas pada piksel ke-n

Ip $=$ intensitasi titik pusat

$\mathrm{T}=$ threshold

Titik p pada citra dengan posisi awal (Xp,Yp), seperti pada Gambar 3. 
Available Online at https://ejurnal.stmik-budidarma.ac.id/index.php/mib DOI 10.30865/mib.v4i1.1850
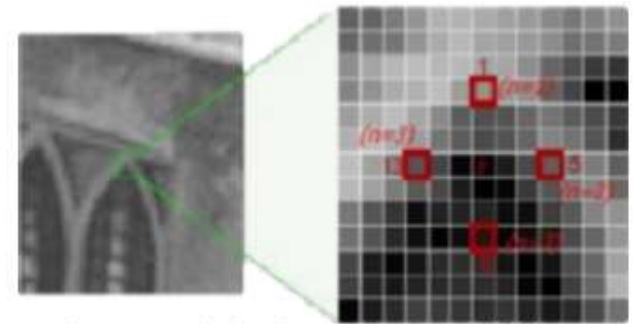

Gambar 3. Letak titik $\mathrm{p}$

\subsection{Flowchart Algoritma FAST Corner Detection}

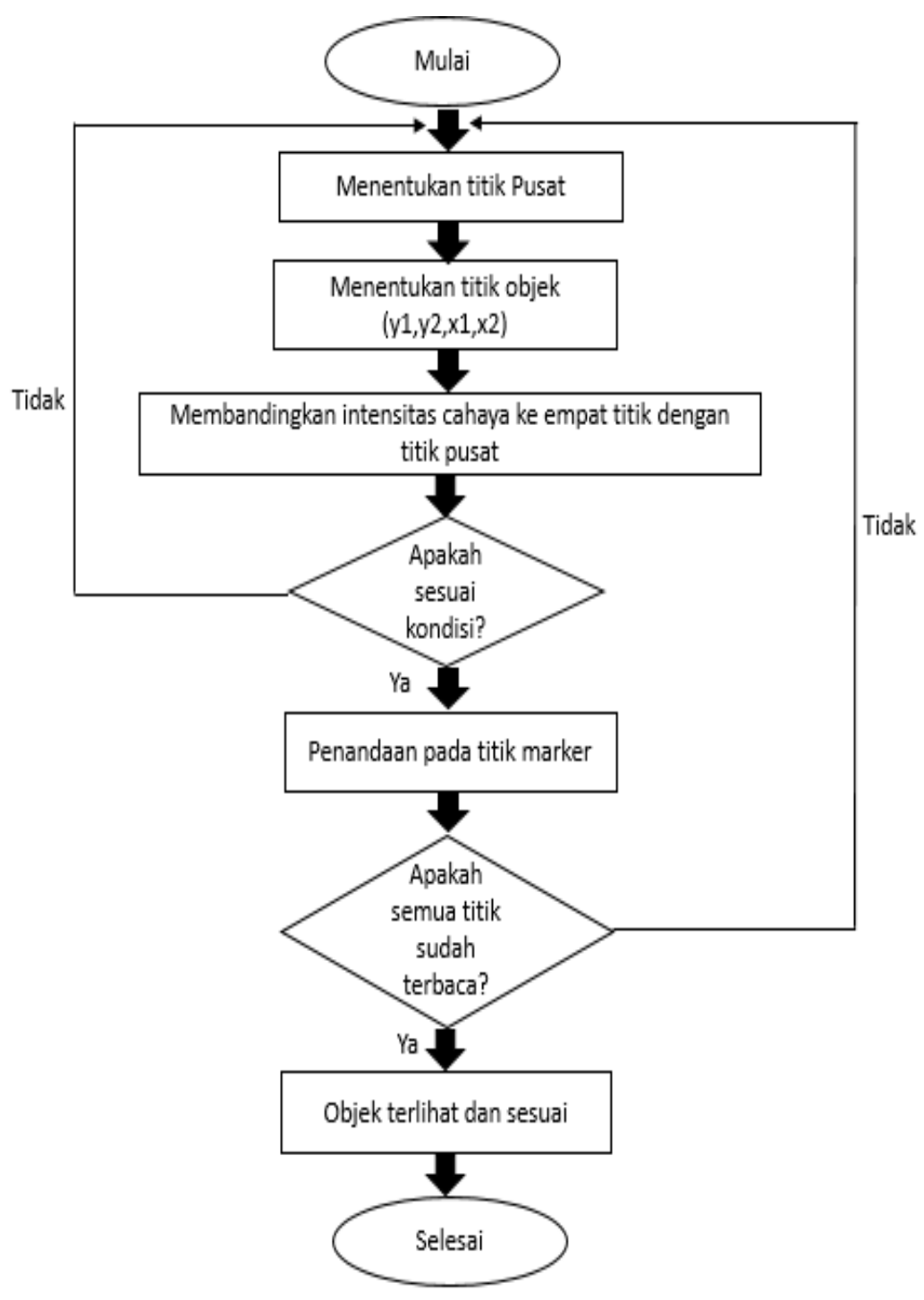

Gambar 4. Flowchart algoritma FAST Corner Detection

Pada Gambar 4 adalah Flowchart algoritma FAST Corner Detection. Penjelasan pada gambar 4 yakni:

a. Menentukan titik pusat pada citra digital.

b. Menentukan titik objek. Pada titik pertama yaitu (X1) yang berada di koordinat (Xp,Yp+3), lalu titik yang kedua (X2) yang terletak di koordinat $(\mathrm{Xp}+3, \mathrm{Yp})$, lalu untuk titik yang ketiga (y1) yang terletak di koordinat (Xp,Yp-3), yang terakhir titik keempat (y2) terletak di koordinat (Xp-3,Yp) [14].

c. Membandingkan keempat titik pada titik pusat, jika terdapat 3 titik yang telah memenuhi syarat yaitu normal, lebih cerah dan lebih gelap, maka titik pusat adalah titik sudut.

d. Mengecek kondisi dari keempat titik pada titik pusat, jika sesuai kondisi maka melanjutkan proses selanjutnya, jika tidak maka kembali menentukan titik pusat.

e. Jika kondisi semua titik memungkinkan maka dibentuk penandaan pada titik marker.

f. Mengecek apakah titik X1, Y1, X2, Y2 dan titik pada marker sudah terbaca, jika sudah maka objek akan terlihat dan sesuai, jika tidak maka kembali menentukan titik pusat. 
Available Online at https://ejurnal.stmik-budidarma.ac.id/index.php/mib DOI 10.30865/mib.v4i1.1850

\section{HASIL DAN PEMBAHASAN}

\subsection{Pembahasan Aplikasi}

Pembahasan aplikasi merupakan tahap pembuatan dengan mengimplemenyasi perancangan yang sudah dibuat. Hasilnya sebagai berikut.

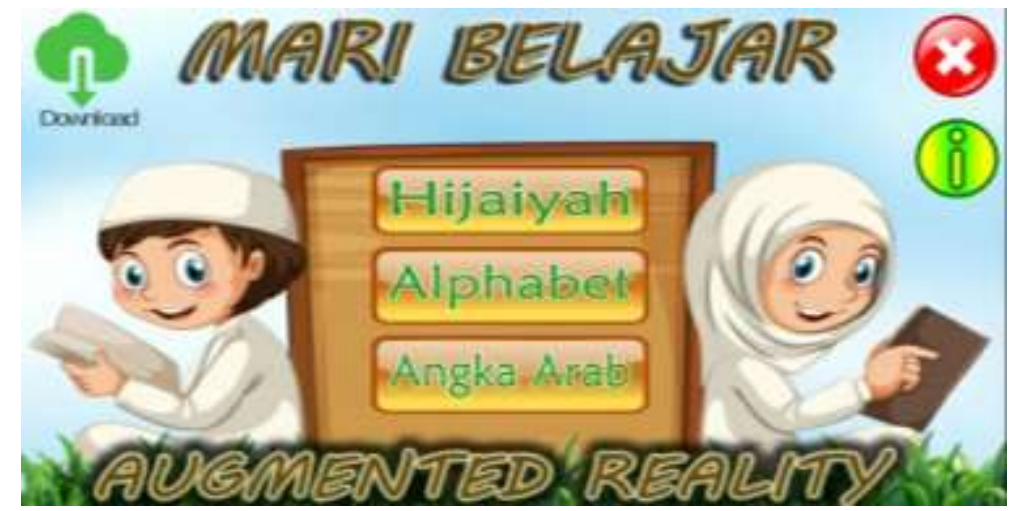

Gambar 5. Halaman Utama

Pada gambar 5 adalah halaman utama pada aplikasi yang terdapat tombol hijaiyah, tombol Alphabet, tombol Angka Arab, tombol Download, tombol Info dan tombol Exit. Untuk menjalankan Augmented Reality, dapat memilih salah satu pilihan yang ada di menu seperti Hijiyah, Alphabet dan Angka Arab.

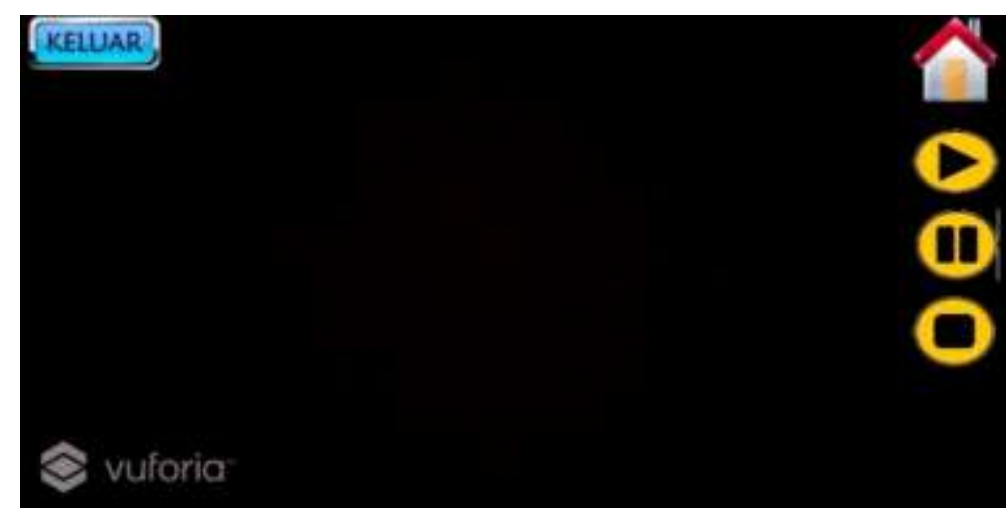

Gambar 6. Tampilan Halaman Scanner

Pada gambar 6 dilampirkan halaman Scanner pada proses Button Hijaiyah, Alphabet dan Angka Arab. Pada halaman Scanner, kamera mulai mendeteksi Marker. Pada halaman ini terdapat tombol yaitu tombol Home, tombol Play Music, tombol Pause Music, tombol Stop Music dan tombol Keluar. Pada tombol Play terdapat lagu untuk pelafalan huruf hijaiyah, angka arab dan alphabet.

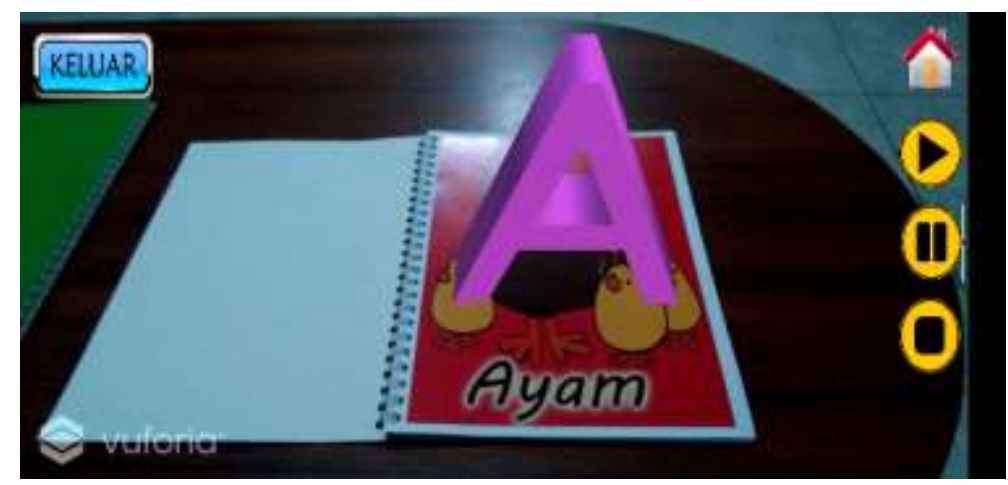

Gambar 7. Menu AR Alphabet

Pada gambar 7 menunjukkan fungsi dari tombol alphabet, ketika menampilkan objek maka akan terdeteksi suara pelafalannya. 
Available Online at https://ejurnal.stmik-budidarma.ac.id/index.php/mib DOI $10.30865 /$ mib.v4i1.1850

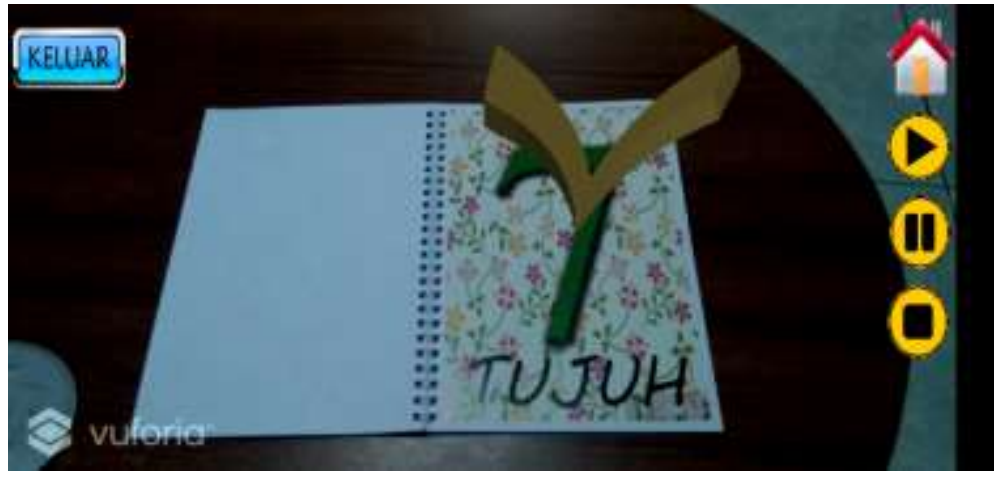

Gambar 8. Scene Dua Angka Arab

Pada gambar 8 menunjukkan fungsi dari tombol angka arab yang menampilkan objek angka arab.

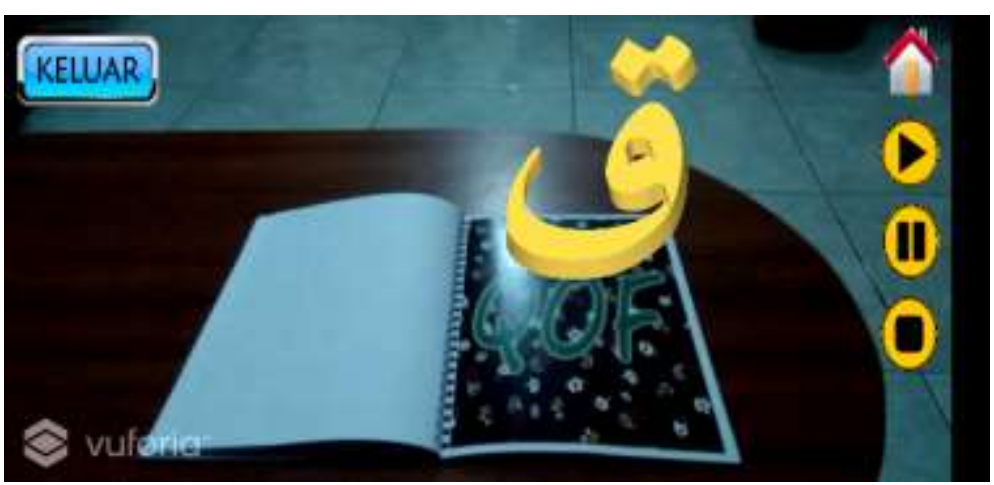

Gambar 9. Scene Tiga Hijaiyah

Pada gambar 9 menunjukkan fungsi dari tombol hijaiyah yang menampilkan objek huruf hijaiyah.

\subsection{Pengujian Aplikasi}

Tabel 1. Pengujian Fitur

\begin{tabular}{clccc}
\hline \multirow{2}{*}{ No } & Fungsi yang diuji & \multicolumn{2}{c}{ Hasil } & Keterangan \\
\hline 1 & Download & X & & Valid \\
2 & Button Hijaiyah & X & Valid \\
3 & Button Alphabet & X & Valid \\
4 & Button Angka Arab & X & Valid \\
5 & Button Play Lagu & X & Valid \\
6 & Button Pause Lagu & X & Valid \\
7 & Button Stop Lagu & X & Valid \\
8 & Button Home & X & Valid \\
9 & Button Exit & X & Valid \\
10 & Suara Objek & X & Valid \\
11 & 3D Objek & X & Valid \\
\hline
\end{tabular}

Pada Tabel 1 adalah tabel pengujian berdasarkan hasil pengujian yang sudah dilakukan. Semua menu dan button berfungsi dan berjalan $100 \%$ dengan keterangan valid sesuai yang diharapkan.

\subsection{Pengujian Algoritma Pada Jarak Marker}

Tabel 2. Pengujian Algoritma Berdasarkan Sudut dan Jarak Marker

\begin{tabular}{ccllll}
\hline Sudut & $\begin{array}{c}\text { Jarak } \\
(\mathrm{cm})\end{array}$ & \multicolumn{1}{c}{ Titik 1 (Y1) } & Titik 2 (X1) & Titik 3 (Y2) & Titik 4 (X2) \\
\hline \multirow{3}{*}{$0^{\circ}$} & 20 & Tidak terbaca & Tidak terbaca & Tidak terbaca & Tidak terbaca \\
& 40 & Tidak terbaca & Tidak terbaca & Tidak terbaca & Tidak terbaca \\
& 60 & Tidak terbaca & Tidak terbaca & Tidak terbaca & Tidak terbaca \\
$45^{\circ}$ & 20 & Terbaca sebagian & Terbaca sebagian & Terbaca sebagian & Terbaca sebagian \\
& 40 & Terbaca sebagian & Tidak terbaca & Tidak terbaca & Tidak terbaca
\end{tabular}


Available Online at https://ejurnal.stmik-budidarma.ac.id/index.php/mib DOI $10.30865 /$ mib.v4i1.1850

\begin{tabular}{ccllll} 
& 60 & Tidak terbaca & Tidak terbaca & Tidak terbaca & Tidak terbaca \\
& 20 & Tidak terbaca & Tidak terbaca & Tidak terbaca & Tidak terbaca \\
$90^{\circ}$ & 40 & Terbaca sebagian & Terbaca sebagian & Terbaca Penuh & Terbaca sebagian \\
& 60 & Terbaca Penuh & Terbaca Penuh & Terbaca Penuh & Terbaca Penuh \\
\hline
\end{tabular}

Pada Tabel 2 merupakan hasil pengujian algoritma pada jarak marker yang terdapat empat titik sudut yaitu X1, $\mathrm{X} 2$, Y1 dan Y2. Ukuran kertas marker yang diuji adalah $13.3 \times 20 \mathrm{~cm}$. Pada titik Y1 dan X1 dengan jarak $20 \mathrm{~cm}$ dan sudut $45^{\circ}$ hanya sebagian objek yang terlihat. Pada titik Y2 dengan jarak 30 dan $40 \mathrm{~cm}$ dengan sudut $90^{\circ}$ objek dapat terlihat namun titik $\mathrm{Y} 1$,X1 dan X2 hanyak membaca sebagian objek. Jadi jika ingin hasil yang maksimal, direkomendasikan jarak $50 \mathrm{~cm}$ dengan sudut $45^{\circ}$ keempat titik dapat menampilkan objek dengan sempurna, serta sudut $90^{\circ}$ dengan jarak $50 \mathrm{~cm}-60 \mathrm{~cm}$ keempat titik dapat menampilkan objek dengan sempurna.

\subsection{Pengujian Tingkat Kecepatan Aplikasi Pada Smartphone}

Tabel 3. Pengujian Kecepatan Aplikasi Pada Smartphone

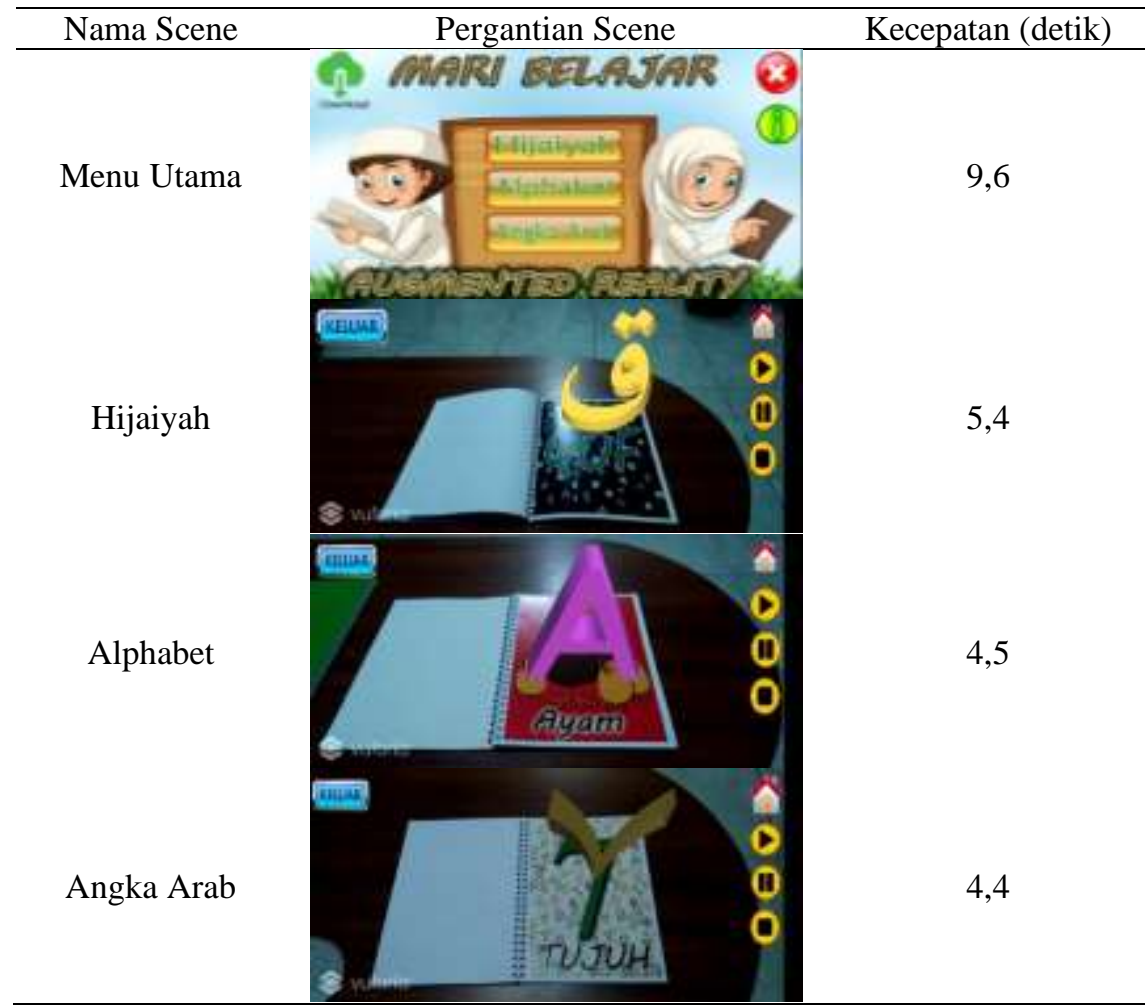

Pada Tabel 3 terdapat pengujian yang dilakukan untuk mengukur tingkat kecepatan aplikasi di berbagai scene dengan menggunakan Smartphone.

\section{KESIMPULAN}

Berdasarkan hasil penelitian, pengujian, dan implementasi pada aplikasi Augmented Reality pengenalan huruf dan angka arab berbasis Android, maka didapatkan kesimpulan sebagai berikut:

1. Pengenalan objek yang berisi huruf hijaiyah, angka arab, dan alphabet dalam bentuk objek 3D dapat berjalan dengan baik. Objek yang ditampilkan sesuai dengan marker yang sudah ditentukan, pemindaian objek dapat membedakan marker satu dengan yang lainnya

2. Berdasarkan pengujian algoritma terhadap titik $\mathrm{x} 1, \mathrm{x} 2, \mathrm{y} 1, \mathrm{y} 2$ dengan ukuran kertas marker 13,3 x $20 \mathrm{~cm}$ terdapat dua opsi jika ingin hasil yang maksimal yaitu jarak $50 \mathrm{~cm}$ dengan sudut $45^{0}$ keempat titik dapat menampilkan objek dengan sempurna, dari rekomendasi jarak $50 \mathrm{~cm}-60 \mathrm{~cm}$ dengan sudut $90^{\circ}$ keempat titik dapat menampilkan objek dengan sempurna.

3. Berdasarkan pengujian tingkat kecepatan aplikasi di smartphone sudah tergolong cukup cepat.

\section{REFERENCES}

[1] M. Jumarlis, "Aplikasi Pembelajaran Smart Hijaiyyah Berbasis Augmented Reality," Ilk. J. Ilm., vol. 10, no. 1, p. 52, 2018.

[2] R. Efendi, E. P. Purwandari, and M. A. Aziz, "Aplikasi Pengenalan Huruf Hijaiyah Berbasis Marker Augmented 
Reality Pada Platform Android,” Pseudocode, vol. 2, no. 2, pp. 124-134, 2015.

[3] M. E. Apriyani, M. Huda, and S. Prasetyaningsih, "Analisis Penggunaan Marker Tracking Pada Augmented Reality Huruf Hijaiyah,” J. INFOTEL - Inform. Telekomun. Elektron., vol. 8, no. 1, p. 71, 2016.

[4] N. Huda, "Aplikasi Bahasa Isyarat Pengenalan Huruf Hijaiyah Bagi Penyandang Disabilitas Tuna Rungu,” J. Sisfokom (Sistem Inf. dan Komputer), vol. 8, no. 1, p. 1, 2019.

[5] R. F. Rahmat, F. Akbar, M. F. Syahputra, M. A. Budiman, and A. Hizriadi, "An Interactive Augmented Reality Implementation of Hijaiyah Alphabet for Children Education," J. Phys. Conf. Ser., vol. 978, no. 1, 2018.

[6] A. R. Muhammad, W. S. Wardhono, and T. Afirianto, "Pengembangan Aplikasi Mobile Augmented Reality Sebagai Media Belajar Pengenalan Dasar Huruf Hijaiyah," J. Pengemb. Teknol. Inf. dan Ilmu Komput. Univ. Brawijaya, vol. 3, no. 1, pp. 1062-1069, 2019.

[7] A. Tahalli, Pengembangan aplikasi iar (iqra' augmented reality) berbasis android sebagai media belajar makhorijul huruf hijaiyah pada mata pelajaran pai di smk negeri 1 magelang. 2017.

[8] D. R. A. Rambli, W. Matcha, and S. Sulaiman, "Fun learning with AR alphabet book for preschool children," Procedia Comput. Sci., vol. 25, pp. 211-219, 2013.

[9] J. White, D. C. Schmidt, and M. Golparvar-Fard, "Applications of augmented reality [Scanning the Issue]," Proc. IEEE, vol. 102, no. 2, pp. 120-123, 2014.

[10] R. A. Ahmadi, J. Adler, and S. L. Ginting, "Teknologi Augmented Reality sebagai Media Pembelajaran Gerakan Shalat," Pros. Semin. Nas. Komput. dan Inform., vol. 2017, pp. 179-186, 2017.

[11] A. Willis and Y. Sui, "An algebraic model for fast corner detection," Proc. IEEE Int. Conf. Comput. Vis., no. Iccv, pp. 2296-2302, 2009.

[12] A. Wiharto and C. Budihartanti, "Aplikasi Mobile Augmented Reality Sebagai Media Pembelajaran Pengenalan Hardware Komputer Berbasis Android,” PROSISKO J. Pengemb. Ris. dan Obs. Sist. Komput., vol. 4, no. 2, pp. 17-24, 2017.

[13] E. Setiawan, U. Syaripudin, and Y. A. Gerhana, "Implementasi Teknologi Augmented Reality pada Buku Panduan Wudhu Berbasis Mobile Android,” J. Online Inform., vol. 1, no. 1, p. 28, 2016.

[14] F. Zuli, "Rancang Bangun Augmented Dan Virtual Reality Menggunakan Algoritma Fast Sebagai Media Informasi 3D Di Universitas Satya Negara Indonesia,” J. Algoritm. Log. dan Komputasi, vol. 1, no. 2, pp. 94-104, 2018. 